\title{
Peramalan Volume Pemakaian Air di PDAM Kota Surabaya dengan Menggunakan Metode Time Series
}

\author{
Moh Ali Asfihani dan Irhamah \\ Jurusan Statistika, Fakultas Matematika dan Ilmu Pengetahuan Alam, Institut Teknologi Sepuluh Nopember (ITS) \\ Jl. Arief Rahman Hakim, Surabaya 60111 \\ e-mail: mohali14@mhs.statistika.its.ac.id, irhamah@statistika.its.ac.id
}

\begin{abstract}
Abstrak-Ketersediaan air bersih di dunia ini sangat terbatas, sedangkan jumlah manusia setiap waktu semakin bertambah. Banyak permasalahan yang sampai saat ini belum dapat diatasi salah satunya adalah penyediaan air bersih. Pada penelitian ini bertujuan untuk memodelkan volume pemakaian air di PDAM Kota Surabaya pada kelompok rumah tangga atau perumahan kelas menengah kebawah, kelas menengah dan kelas menengah keatas. Sehingga manfaat yang diharapkan dari penelitian ini adalah mendapatkan hasil ramalan yang tepat untuk volume pemakaian air di PDAM Kota Surabaya pada kategori tersebut. Metode yang digunakan dalam penelitian ini adalah metode Time Series yaitu menggunakan metode ARIMA dan fungsi transfer. Variabel penelitian yang digunakan dalam penelitian ini adalah jumlah pelanggan sebagai deret input dan volume pemakaian air sebagai deret output. Kesimpulan yang diperoleh dalam penelitian ini adalah karakteristik jumlah pelanggan memiliki rata-rata pertumbuhan pelanggan yang berfluktuasi sedangkan secara keseluruhan cenderung meninggkat, sedangkan jumlah volume pemakaian air juga mengalami fluktuasi atau perubahan naik maupun turun. Dari hasil perbandingan metode untuk rumah tangga kelas menengah kebawah metode ARIMA adalah yang terbaik, sedangkan untuk rumah tangga kelas menengah adalah metode fungsi transfer yang terbaik dan untuk rumah tangga kelas menengah keatas metode yang terbaik adalah ARIMA.
\end{abstract}

Kata Kunci-ARIMA, Fungsi Transfer, Jumlah Pelanggan, Volume Pemakaian Air

\section{PENDAHULUAN}

$\mathrm{T}$ OTAL jumlah air yang ada, hanya $3 \%$ yang tersedia sebagai air tawar yang dimana lebih dari dua per tiga bagiannya berada dalam bentuk es di glasier dan es kutub, sedangkan sisanya merupakan air laut. Sampai saat ini, penyediaan air bersih untuk masyarakat di Indonesia masih dihadapkan pada beberapa permasalahan yang belum dapat diatasi sepenuhnya. Salah satu masalah yang masih dihadapi sampai saat ini yaitu masih rendahnya tingkat pelayanan air bersih untuk masyarakat.

Berbagai penelitian telah dilakukan sebelumnya terhadap volume pemakaian air diantaranya adalah [3] melakukan peramalan volume produksi air di PDAM Kabupaten Bojonegoro berdasarkan jumlah pelanggan dan volume konsumsi air dengan menggunakan metode fungsi transfer dan dihasilkan bahwa dengan menggunakan metode fungsi transfer mendapatkan hasil yang lebih baik atau error lebih kecil dibandingkan dengan hanya menggunakan metode ARIMA karena selain dipengaruhi oleh volume produksi air pada periode 1, 22, dan 23 sebelumnya juga dipengaruhi oleh jumlah pelanggan pada periode $23,24,45$, dan 46 sebelumnya. [2] meneliti tentang peramalan volume pemakaian air sektor rumah tangga di Kabupaten Gresik dengan menggunakan fungsi transfer dan diperoleh hasil volume pemakaian air bulan ini dipengaruhi oleh volume pemakaian pada 12 dan 24 sebelumnya, serta dipengaruhi oleh jumlah pelanggan pada 8 , 20 dan 32 periode sebelumnya. Oleh karena itu PDAM Kota Surabaya perlu melakukan peramalan volume pemakaian air agar semua masyarakat yang berada di Kota Surabaya bisa menikmati dan mendapatkan layanan air bersih.

Tujuan dari penelitian ini adalah mendapatkan karakteristik data volume pemakaian air PDAM Kota Surabaya, mendapatkan model peramalan terbaik dari data volume pemakaian air PDAM Kota Surabaya dengan menggunakan metode time series dan mendapatkan peramalan dari data volume pemakaian air PDAM Kota Surabaya untuk beberapa periode mendatang. Penelitian ini diharapkan memberikan informasi tambahan kepada pihak PDAM Surya Sembada Surabaya dengan menghasilkan ramalan yang tepat untuk volume pemakaian air yang akan datang sehingga dapat menjadi dasar pertimbangan serta perencanaan yang efektif dan efisien bagi perusahaan misalnya dalam hal penambahan volume air produksi dan penambahan sumber mata air baku yang baru sehingga kebutuhan masyarakat Surabaya akan air bersih dapat terpenuhi secara optimal. Metode yang digunakan dalam penelitian ini adalah ARIMA dan fungsi transfer.

\section{TINJAUAN PUSTAKA}

\section{A. Time Series}

Time series merupakan deretan atau rangkaian observasi yang diambil dari waktu ke waktu dan dicatat menurut urutan waktu kejadiannya dengan interval waktu yang tetap (konstan) secara runtun. Tujuan mempelajari time series adalah memahami dan memberikan gambaran untuk membuat suatu mekanisme, peramalan nilai masa depan dan optimalisasi sistem control.

\section{B. Model ARIMA Box-Jenkins}

Model ARIMA Box-Jenkins merupakan penggabungan antara model autoregressive (AR) dan moving average (MA) serta proses differencing orde $d$ terhadap data time series. 
Bentuk umum model ARIMA $(p, d, q)$ non musiman adalah sebagai berikut [5].

$$
\phi_{p}(B)(1-B)^{d} Y_{t}=\theta_{0}+\theta_{q}(B) a_{t}
$$

dengan,

$\phi_{p} \quad:$ koefisien komponen AR non musiman dengan orde $p$

$\theta_{q}$ : koefisien komponen MA non musiman dengan orde $q$

$\phi_{p}(B):\left(1-\phi_{1} B-\ldots-\phi_{p} B^{p}\right)$

$\theta_{q}(B):\left(1-\theta_{1} B-\ldots-\theta_{q} B^{q}\right)$

$(1-B)^{d}$ : operator untuk differencing orde $d$

$a_{t} \quad$ : nilai residual pada saat $\mathrm{t}$.

Metode ARIMA Box-Jenkins memiliki empat langkah analisis yaitu identifikasi model, estimasi parameter dan uji signifikansi, cek diagnosa, dan peramalan. Suatu data time series dapat dikatakan telah stasioner, apabila mean dan varians dari data yang digunakan tidak ada perubahan sistematis dari kedua ciri data tersebut. Untuk menstasionerkan data terhadap varians maka dilakukan transformasi Box-Cox. Sedangkan, untuk menstasionerkan data terhadap mean maka dilakukan differencing. Nilai-nilai dari model ARIMA dapat diduga berdasarkan pola dari plot ACF (q) dan PACF (p) pada data yang telah stasioner. Selanjutnya melakukan estimasi parameter uji signifikansi dengan metode Maximum Likelihood Estimation (MLE). Selanjutnya dilakukan cek diagnosa yaitu pengujian untuk memeriksa residual data telah memenuhi asumsi white noise dengan uji Ljung-Box. Sedangkan kenormalan suatu residual data menggunakan uji Kolmogorov Smirnov. Jika residual belum memenuhi asumsi kenormalan, maka dilakukan deteksi outlier. Pemilihan model terbaik adalah model yang memiliki nilai kriteria error terkecil. Pada penelitian ini menggunakan kriteria berdasarkan kesalahan peramalan out sample MAPE dan RMSE.

\section{Metode Fungsi Transfer}

Analisis fungsi transfer merupakan salah satu alternatif untuk menyelesaikan permasalahan apabila terdapat lebih dari satu deret berkala, dimana keadaan ini sering disebut multivariat deret waktu dalam satistika.

Menurut [1] model fungsi transfer bivariat ditulis dalam 2 bentuk umum, bentuk pertama adalah ditampilkan pada persamaan (2.17).

$$
Y_{t}=v(B) X_{t}+N_{t}
$$

Dengan;

$$
\begin{aligned}
Y_{t}= & \text { Deret } \text { Output } \\
X_{t}= & \text { Deret Input } \\
N_{t}= & \text { pengaruh kombinasi dari seluruh faktor yang } \\
& \text { mempengaruhi } Y_{t}, \text { dan disebut dengan gangguan } \\
& \text { (noise }) \\
v(B)= & \left(v_{0}+v_{1} B+v_{2} B_{2}+\ldots+v_{k} B_{k}\right), \text { dimana } k \\
& \text { adalah orde fungsi transfer. } \\
B \quad= & \text { Operator mundur }
\end{aligned}
$$

Orde fungsi transfer adalah $k$ (menjadi orde tertinggi untuk proses pembedaan dan ini kadang-kadang dapat menjadi lebih besar, sehingga model fungsi transfer dapat ditulis dalam model kedua sebagai berikut.

$$
y_{t}=\frac{\omega(B)}{\delta(B)} X_{t-b}+n_{t}
$$

dimana;

$$
y_{t}=\frac{\omega(B)}{\delta(B)} X_{t-b}+\frac{\theta(B)}{\emptyset(B)} a_{t}
$$

$$
\begin{aligned}
& \omega(B)=\omega_{0}-\omega_{1} B-\omega_{2} B^{2}-\cdots-\omega_{s} B^{s} \\
& \delta(B)=1-\delta_{1} B-\delta_{2} B^{2}-\cdots-\delta_{r} B^{r} \\
& \theta(B)=1-\theta_{1} B-\theta_{2} B^{2}-\cdots-\theta_{q} B^{q} \\
& \varnothing(B)=1-\emptyset_{1} B-\emptyset_{2} B^{2}-\cdots-\emptyset_{p} B^{p}
\end{aligned}
$$

$y_{t}=$ Nilai $Y_{t}$ yang stasioner

$X_{t} \quad=$ Nilai $X_{t}$ yang stasioner

$a_{t}=$ eror dan $r, s, p, q$ dan $b$ adalah konstanta.

Pernyataan $\theta(B)$ dan $\varnothing(B)$ secara berturut-turut menyatakan operator rata-rata bergerak atau moving average dan operator autoregresif (AR) untuk gangguan $n_{t}$. Sedangkan untuk $r, s, b$ menunjukkan penentuan parameter model fungsi transfer yang menghubungkan $y_{t}$ dengan $x_{t}$ dan $p, q$ menunjukkan pembentukan parameter dari model gangguan (noise model). Umumnya, suatu output $\left(Y_{t}\right)$ dapat juga dipengaruhi oleh beberapa input. Menurut [4], model tersebut merupakan model fungsi transfer multi input, yang ditampilkan pada persamaan (2.20).

dimana:

$$
y_{t}=\sum_{j=1}^{k} \frac{\omega_{j}(B)}{\delta_{j}(B)} x_{j t-b j}+\frac{\theta(B)}{\emptyset(B)} a_{t}
$$

$\omega_{j}(B)=$ Operator moving average order $s_{j}$ untuk deret ke- $j$

$\delta_{j}(B)=$ Operator autoregressive order $r_{j}$ untuk deret ke- $j$

$\theta(B)=$ Operator moving average order $q$

$\emptyset(B)=$ Operator autoregressive order $p$

Pembentukan model fungsi transfer untuk deret input $\left(X_{t}\right)$ dan deret output $\left(Y_{t}\right)$ tertentu meliputi 4 tahap utama dan beberapa sub utama dan beberapa sub tahab. Empat tahap utama tersebut adalah identifikasi model fungsi transfer, penaksiran parameter model fungsi transfer, uji diagnostik model fungsi transfer dan penggunaan model fungsi transfer untuk peramalan [1].

Langkah-langkah yang perlu dilakukan dalam pengidentifikasian model fungsi transfer terdiri atas 7 tahap, yaitu:

I. Mempersiapkan Deret Input dan Deret Output

[1] menjelaskan tentang beberapa hal yang perlu dilakukan dalam mempersiapkan deret input dan deret output adalah memeriksa :

a. Transformasi perlu dilakukan terhadap deret input dan output karena transformasi yang tepat dapat mengatasi ragam yang tidak stasioner,

b. Differencing juga harus dilakukan untuk deret input dan deret output supaya menjadi stasioner apabila tidak stasioner terhadap rata-rata, dan

c. Pengaruh musiman pada deret input dan deret output jua perlu dihilangkan, karena menyebabkan nilai-nilai $(r, s, b)$ menjadi lebih kecil dibandingkan dengan jika tidak dilakukan pengujian terhadap musiman (walaupun bukan merupakan persyaratan dari fungsi transformasi). Dengan demikian, deret data yang telah ditransformasi dan telah sesuai disebut dengan $x_{t}$ dan $y_{t}$.

II. Prewhitening Deret Input

Menurut [1], deret input dapat dibuat lebih mudah diatur dengan dilakukan prewhitening, maksudnya adalah dengan menghilangkan seluruh pola yang diketahui sehingga yang tertinggal hanya white noise. Model untuk deret input yang telah dilakukan prewhitening ditampilkan pada persamaan 
(2.21).

$$
a_{t}=\frac{\emptyset_{x}(B)}{\theta_{x}(B)} x_{t}
$$

Deret $a_{t}$ inilah yang disebut dengan prewhitening deret input $x_{t}, a_{t}$ adalah residual yang telah white noise.

\section{Prewhitening Deret Output}

Transformasi prewhitening untuk deret input $x_{t}$ seperti pada persamaan (2.21) harus diterapkan juga terhadap deret output $y_{t}$ [1]. Prewhitening deret output dilakukan agar fungsi transfer dapat memetakan $x_{t}$ kedalam $y$. Deret $y_{t}$ yang telah di prewhitening disebut deret $\beta_{t}$ yaitu:

$$
\beta_{t}=\left(\frac{\Phi_{x}(B)}{\theta_{x}(B)}\right) y_{t}
$$

IV.Perhitungan Korelasi Silang Deret Input dan Deret Output yang telah di Prewhitening

Menurut [4], fungsi korelasi silang tidak hanya mengukur kekuatan hubungan, tetapi juga mengukur arah hubungan itu, sehingga untuk melihat hubungan antara deret input $\left(X_{t}\right)$ dan deret output $\left(Y_{t}\right)$ secara grafik, perlu menghitung CCF (Cross Correlation Function), $\rho_{x, y}(k)$ untuk kedua lag baik positif maupun negatif.

Korelasi silang antara deret input $\left(a_{t}\right)$ dan deret output $\left(\beta_{t}\right)$ yang telah di prewhitening dan disesuaikan adalah:

$$
r_{a \beta}(k)=\frac{c_{a \beta}(k)}{s_{a} s_{\beta}}
$$

dengan $r_{a \beta}$ adalah nilai korelasisilang antara deret input $\left(a_{t}\right)$ dan deret output $\left(\beta_{t}\right)$ yang telah di prewhitening, $C_{a \beta}$ adalah nilai kovarians antara deret input $\left(a_{t}\right)$ dan deret output $\left(\beta_{t}\right)$ yang telah di prewhitening, $S_{a}$ adalah nilai standart deviasi dari deret input $\left(a_{t}\right)$ yang telah di prewhitening, dan $S_{\beta}$ adalah nilai standart deviasi dari deret output $\left(\beta_{t}\right)$ yang telah di prewhitening.

V. Penetapan Penetapan $r, s, b$ untuk Model Fungsi Transfer

Tiga parameter kunci dalam membentuk model fungsi transfer adalah $(r, s, b)$ dimana:

$$
\begin{aligned}
& r=\text { adalah derajat fungsi } \delta(B), \\
& s=\text { adalah derajat fungsi } \omega(B), \text { dan } \\
& b=\text { adalah keterlambatan yang dicatat dalam subskrip } \\
& \text { dari } X_{t-b}
\end{aligned}
$$

kenyataan-kenyataan ini biasanya disimpulkan ke dalam tiga bentuk prinsip petunjuk, yang ditunjukkan untuk membantu seorang peramal dalam menentukan nilai yang tepat untuk $(b, r, s)$ yaitu sebagai berikut:

a. Sampai lag waktu ke- $b$, korelasi silang tidak akan berbeda dari nol secara signifikan

b. Untuk $s$ time lag selanjutnya, korelasi silang tidak akan memperhatikan adanya pola yang jelas.

c. Untuk $r$ time lag selanjutnya, korelasi silang akan memperlihatkan suatu pola yang jelas.

[4], memberikan suatu petunjuk dalam menentukan nilai $b$, $r$, dan $s$ yang jelas.

a) Untuk kasus $r=0$, fungsi transfer hanya mengandung sejumlah bobot respons implus yang dimulai dari $v_{b}=0$ dan $v_{b+s}=-\omega_{s}$

b) Untuk kasus $r=1$, bobot respons implus menunjukkan pola menurun secara eksponensial dari $v_{b}$ jika $s=0$, dari $v_{b+1}$ jika $s=1$ dan $v_{b+2}$ jika $s=2$.

c) Untuk kasus $r=2$, bobot respon implus menunjukkan pola gelombang sinus teredam.

\section{VI.Pengujian Noise Series}

Menurut [4] jika bobot respon implus $v$ diperoleh, maka perhitungan nilai taksiran pendahuluan dari deret gangguan $n_{t}$.

$$
n_{t}=y_{t}-\sum_{j=1}^{m} \hat{v}_{j}(B) x_{j t}
$$

VII. Penetapan $\left(p_{n}, q_{n}\right)$ untuk Model ARIMA $\left(p_{n}, 0, q_{n}\right)$ dari

Deret Noise

[1] menjelaskan bahwa penetapan parameter deret gangguan $(p, q)$ dilakukan dengan menganalisis nilai-nnilai $n_{t}$ menggunakan metode ARIMA biasa untuk menemukan apakah terdapat model ARIMA $\left(p_{n}, 0, q_{n}\right)$ yang tepat untuk menjelaskan deret tersebut. Fungsi $\emptyset_{n}(B)$ dan $\theta_{n}(B)$ untuk deret noise $n_{t}$ diperoleh untuk mendapatkan persamaan berikut.

$$
\emptyset_{n}(B) n_{t}=\theta_{n}(B) a_{t}
$$

$n_{t}$ adalah deret gangguan (noise series).

\section{Perusahaan Daerah Air Minum (PDAM) Surabaya}

PDAM Kota Surabaya adalah badan usaha milik daerah, yang menangani masalah pengelolaan air bersih di Kota Surabaya. Kantor PDAM Kota Surabaya berada di Jalan Prof Dr. Moestopo, lokasinya dekat dengan stasiun Gubeng. PDAM Kota Surabaya mendapat penghargaan dari Persatuan Perusahaan Air Minum Seluruh Indonesia (Perpamsi) sebagai penyelenggara pelayanan air minum terbaik pertama di Indonesia untuk kategori PDAM Metropolis.

\section{METODOLOGI PENELITIAN}

\section{A. Sumber Data}

Data yang digunakan dalam penelitian ini merupakan data sekunder yang diperoleh dari Perusahaan Air Minum Daerah (PDAM) di Kota Surabaya. Data tersebut adalah volume pemakaian air bulanan dan jumlah pelanggan, dimana data in sampel mulai Juli 2008 sampai Desember 2015 sebanyak 90 data, dan data out sampel mulai Januari 2016 sampai Oktober 2016 sebanyak 10 data.

\section{B. Variabel Penelitian}

Variabel penelitian yang digunakan dalam penelitian ini adalah data volume pemakaian air dan jumlah pelanggan periode bulanan PDAM Kota Surabaya. Data tersebut terdiri dari 11 kelompok pelanggan, akan tetapi diambil 3 kelompok pelanggan yang memiliki volume pemakaian air terbesar yaitu kategori 3A (rumah tangga kelas menengah kebawah), kategori 4A (rumah tangga kelas menengah) dan kategori 4B (rumah tangga kelas menengah keatas), sehingga terdapat 3 kelompok data jumlah pelanggan dan data volume pemakaian air dari kelompok pelanggan tersebut, berikut adalah variabel-variabel tersebut.

1. Variabel $Y_{t}$ adalah volume pemakaian air (Deret Output).

2. Variabel $X_{t}$ adalah jumlah pelanggan (Deret Input).

\section{Langkah Analisis}

Langkah-langkah yang dilakukan dalam penelitian ini dapat dijelaskan sebagai berikut.

1. Melakukan analisis deskriptif pada data volume pemakaian air dan jumlah pelanggan dengan mengunakan mean, standar deviasi, minimum dan maksimum.

2. Mempersiapkan deret input (jumlah pelanggan) dan deret 
output (volume pemakaian air)

3. Melakukan identifikasi pada time series plot, plot ACF dan PACF. Jika tidak stasioner dalam varians maka dilakukan transformasi, sedangkan tidak stasioner dalam mean maka dilakukan differencing.

4. Penentuan model ARIMA untuk jumlah pelanggan.

5. Melakukan uji kesesuaian model dengan memenuhi asumsi white noise dan kenormalan.

6. Melakukan prewhitening pada deret input untuk memperoleh $\alpha_{\mathrm{t}}$.

7. Melakukan prewhitening pada deret output untuk memperoleh $\beta_{\mathrm{t}}$.

8. Melakukan perhitungan korelasi silang (Cross Correlation) dan autokorelasi untuk deret input dan output yang telah di prewhitening.

9. Menetapkan nilai $(b, r, s)$ yang menghubungkan deret input dan output untuk menduga model fungsi transfer.

10. Penaksiran awal deret noise $\left(n_{t}\right)$ dan perhitungan autokorelasi, parsial dan spektrum garis untuk deret ini.

11. Menetapkan $\left(p_{n}, q_{n}\right)$ untuk model ARIMA $\left(p_{n}, 0, q_{n}\right)$ dari deret noise $\left(n_{t}\right)$.

12. Penaksiran parameter model fungsi transfer. Penaksiran parameter dari model fungsi transfer menggunakan metode Conditional Least Square.

13. Uji diasnostik model fungsi transfer dengan menghitung autokorelasi untuk nilai sisa model $(b, r, s)$ yang menghubungkan deret output dan deret input dan menghitung korelasi silang antara nilai sisa dengan residual $\left(\alpha_{t}\right)$ yang telah di prewhitening.

14. Melakukan peramalan nilai-nilai yang akan datang dengan menggunakan model fungsi transfer.

\section{ANALISIS DAN PEMBAHASAN}

\section{A. Karakteristik Jumlah Pelangan dan Volume Pemakaian Air di PDAM Kota Surabaya}

Karakteristik data jumlah pelanggan dan volume pemakaian air di PDAM Kota Surabaya disajikan dalam bentuk tabel di bawah ini sehingga dapat diperoleh informasi yang mudah dipahami.

Tabel 1

\begin{tabular}{lcc}
\hline \multicolumn{3}{c}{ Statistika Deskriptif } \\
\hline Kategori & $\begin{array}{c}\text { Rata-rata } \\
\text { Pemakaian } \\
\text { Air }\left(\mathrm{m}^{3}\right)\end{array}$ & $\begin{array}{c}\text { Rata-rata } \\
\text { Pertumbuhan } \\
\text { Pelanggan }\end{array}$ \\
\hline 3A & 5.117 .973 & +82 \\
4A & 4.073 .034 & +398 \\
4B & 3.966 .440 & +87 \\
Total Keseluruhan & 19.043 .315 & +892 \\
\hline \hline
\end{tabular}

Berdasarkan tabel 4.1 diatas dapat dijelaskan bahwa rata-rata pemakaian air setiap kelompok pelanggan perbulan adalah berbeda-beda begitu juga rata-rata pertumbuhan pelanggan perbulan. Rata-rata pemakaian air perbulan terbesar di PDAM Kota Surabaya adalah kelompok rumah tangga kelas menengah kebawah sebesar $5.117 .973 \mathrm{~m}^{3}$, rumah tangga kelas menengah sebesar 4.073.034 $\mathrm{m}^{3}$ dan rumah tangga kelas menengah keatas adalah 3.966.440 $\mathrm{m}^{3}$, sedangkan rata-rata pertumbuhan pelanggan masing-masing adalah 82, 398 dan 87 .

\section{B. Pemodelan pada Rumah Tangga Kelas Menengah Kebawah}

Proses pemodelan ARIMA dari data volume pemakaian air rumah tangga kelas menengah kebawah dilakukan transformasi dan differencing sehingga data telah stasioner dalam mean dan varians.

Secara umum hasil pengujian parameter dan pemeriksaan diagnosis ditunjukkan pada tabel 4.14 dibawah.

Tabel 2

Hasil Pengujian Parameter dan Pemerigsaan Diagnosis pada Volume Pemakaian Air Kategori 3A

\begin{tabular}{lclc}
\hline \multicolumn{1}{c}{ Model } & Parameter & \multicolumn{2}{l}{ Pemeriksaan Diagnosis } \\
\hline ARIMA $(1,1,[12])$ & Signifikan & White Noise & Normal \\
ARIMA $([1,4], 1,[12])$ & Signifikan & White Noise & Normal \\
ARIMA $([1,4,11], 1,[12])$ & Signifikan & White Noise & Normal \\
\hline \hline
\end{tabular}

Berdasarkan tabel 2 menunjukkan bahwa semua model mempunyai nilai parameter signifikan, sedangkan dalam pemeriksaan diagnosis model berdistribusi normal dan white noise.

Tabel 3

Pemilihan Model Tebaik Kriteria In Sample pada Volume Pemakaian Air

\begin{tabular}{lc}
\multicolumn{2}{c}{ Kategori 3A } \\
\hline \hline \multicolumn{1}{c}{ Model } & AIC \\
\hline ARIMA (1,1,[12]) & $-1797,43$ \\
ARIMA ([1,4],1,[12]) & $-1796,38$ \\
ARIMA ([1,4,11],1,[12]) & -1794.38 \\
\hline \hline
\end{tabular}

Tabel 3 menunjukkan bahwa dengan menggunakan nilai AIC maka model yang terbaik adalah ARIMA $(1,1,[12])$ dengan nilai AIC sebesar -1797,43.

Selanjutnya dengan menggunakan cara yang sama didapatkan model yang terbaik untuk deret input adalah ARIMA $(1,1,0)$ dengan nilai AIC sebesar 1433.448. Secara matematis dapat di tulis sebagai berikut:

$x_{t}=859.42865+x_{t-1}+0.78485 x_{t-1}-0.78485 x_{t-2}+a_{t}$ Sehingga prewhitening deret input adalah

$a_{t}=x_{t}-859.42865-x_{t-1}-0.78485 x_{t-1}+0.78485 x_{t-2}$ Sedangkan prewhitening deret output adalah

$\beta_{t}=y_{t}-859.42865-y_{t-1}-0.78485 y_{t-1}+0.78485 y_{t-2}$

Langkah selanjutnya adalah melakukan identifikasi (b,r,s) berdasarkan plot CCF (Crosscorrelation Function).

Gambar 1 plot CCF antara deret input (jumlah pelanggan rumah tangga kelas menengah kebawah) dengan deret output (volume pemakaian air rumah tangga kelas menengah kebawah). Berdasarkan plot CCF orde (b,r,s) dapat diketahui nilainya pada tabel 4 , karena residual tidak memenuhi asumsi white noise maka dilakukan pemodean ARMA pada deret noise yang dapat diduga dari plot ACF dan PACF berikut. 

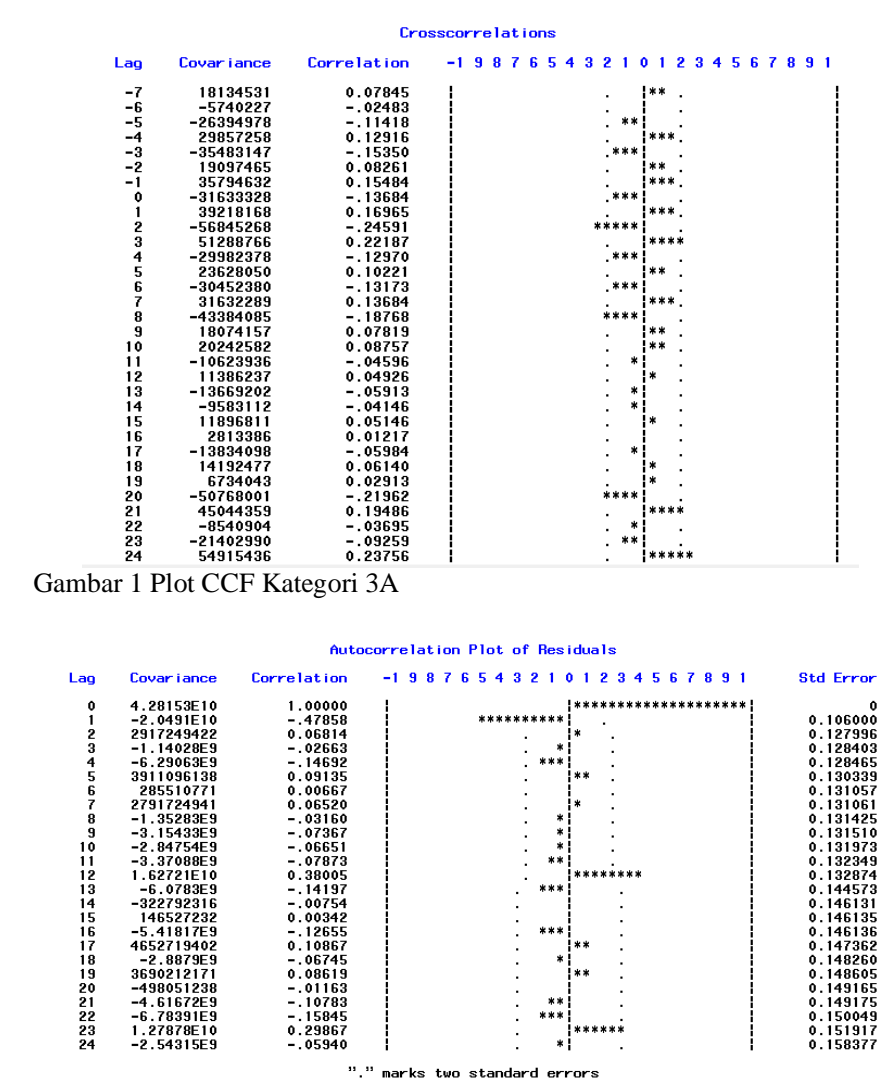

Gambar 2 Plot ACF Pada Residual Deret Noise untuk Kategori 3A

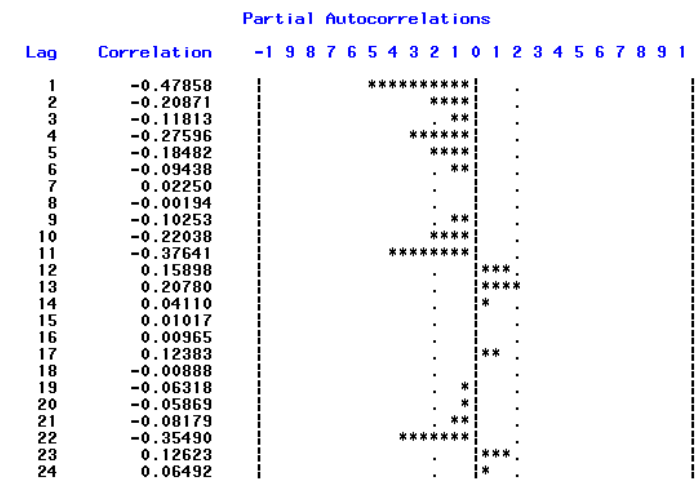

Gambar 3 Plot PACF Pada Residual Deret Noise untuk Kategori 3A

Setelah dilakukan pungujian parameter dan diagnosis model didapatkan hasil sebagai berikut.

Tabel 4

Pengujian Parameter Model Fungsi Transfer Kategori 3A

\begin{tabular}{lccc}
\hline \multicolumn{1}{c}{ Model } & Parameter & Estimasi & $t_{\text {hitung }}$ \\
\hline & MA 1 & 0.70559 & 5.09 \\
$\mathrm{~b}=2, \mathrm{r}=0, \mathrm{~s}=0$ dan ARMA & MA 23 & -0.31234 & -2.18 \\
$([12],[1,23])$ & AR 12 & 0.38637 & 4.03 \\
& $\omega_{0}$ & 25.37949 & 5.80 \\
& MA 23 & -0.50936 & -3.77 \\
$\mathrm{~b}=2, \mathrm{r}=0, \mathrm{~s}=0$ dan ARMA & AR 12 & 0.37599 & 3.69 \\
$([12],[23])$ & $\omega_{0}$ & 15.51548 & 1.32 \\
\hline
\end{tabular}

Tabel 4 diketahui bahwa dugaan model dengan nilai $b=2$, $\mathrm{r}=0, \mathrm{~s}=0$ dengan ARMA ([12],[1,23]) memiliki nilai $t_{\text {hitung }}>$ $t_{\text {tabel }}$ pada taraf signifikan $\alpha=5 \%$, kesimpulannya parameter signifikan. Selanjutnya adalah dilakukan pengujian diagnosis yaitu residual white noise dan berdistribusi normal.

Tabel 5 menunjukkan bahwa residual model dugaan awal untuk fungsi transfer $b=2, r=0, s=0$ dan ARMA ([12],[1,23]) pada deret input (jumlah pelanggan untuk kategori $3 \mathrm{~A}$ ) dengan deret output (pemakaian air untuk kategori 3A) diketahui nilai Chi-Square $_{\text {hitung }}<$ Chi-Square tabel $_{\text {sehingga residual memenuhi }}$ asumsi white noise.

Tabel 5

Pemeriksaan Diagnosis Model Fungsi Transfer Kategori 3A

\begin{tabular}{lllll}
\hline \hline \multirow{2}{*}{ Model (b,r,s) } & \multicolumn{4}{c}{ Pemeriksaan Diagnosis } \\
\cline { 2 - 5 } & \multicolumn{1}{c}{ Lag } & \multicolumn{1}{c}{ Df } & Chi-Square & Kolmogorov \\
\hline \multirow{2}{*}{ b=2,r=0,s=0 dan } & 6 & 3 & 7.73 & \\
ARMA ([12],[1,23]) & 12 & 9 & 10.13 & 0.076104 \\
& 24 & 21 & 23.02 & \\
b=2,r=0,s=0 dan & 6 & 4 & 30.93 & \\
ARMA ([12],[23]) & 12 & 10 & 32.01 & 0.108408 \\
& 18 & 16 & 43.53 & \\
\hline \hline
\end{tabular}

Tabel 6

Model Fungsi Transfer Terbaik untuk Kategori 3A

\begin{tabular}{cc}
\hline \hline Model Fungsi Transfer & AIC \\
\hline $\mathrm{b}=2, \mathrm{r}=0, \mathrm{~s}=0$ dan ARMA $([12],[1,23])$ & 2323.799 \\
\hline \hline
\end{tabular}

Secara umum model fungsi transfer yang terpilih adalah $\mathrm{b}=2, \mathrm{r}=0, \mathrm{~s}=0$ dan ARMA $([12],[1,23])$ dan dapat ditulis sebagai berikut:

$$
\begin{aligned}
y_{t}= & (0.38637) y_{t-12}+(25.37949) x_{t-2}- \\
& (0.38637)(25.37949) x_{t-14}+a_{t}-0.70559 a_{t-1}+ \\
& 0.31234 a_{t-23}
\end{aligned}
$$

Dari model diatas dapat dijelaskan bahwa volume pemakaian air bulan ini di PDAM Kota Surabaya kelompok rumah tangga kelas menengah kebawah dipengaruhi oleh volume pemakaian air pada periode 12 bulan sebelumnya serta jumlah pelanggan pada periode 2 dan 14 bulan sebelumnya.

\section{Permodelan pada Rumah Tangga Kelas Menengah}

Data dilakukan transformasi dan diffrencing sehingga data telah stasioner dalam mean dan varians. Hasil dari pemodelan ARIMA didapatkan model yang terbaik adalah ARIMA $([1,4], 1,[1,12])$ untuk volume pemakaian air rumah tangga kelas menengah dengan nilai AIC sebesar -1786.41. Sedangkan model yang terbaik untuk model fungsi transfer adalah $\mathrm{b}=5, \mathrm{r}=0, \mathrm{~s}=0$ dengan deret noise ARMA $([1,4,12],[1,23])$.

\section{Permodelan pada Rumah Tangga Kelas Menengah Keatas}

Data dilakukan diffrencing sehingga data telah stasioner dalam mean dan varians. Hasil dari pemodelan ARIMA didapatkan model yang terbaik adalah ARIMA $([1,2,3,4,21], 1,[12])$ untuk volume pemakaian air rumah tangga kelas menengah keatas dengan nilai AIC sebesar 2310.007. Sedangkan model yang terbaik untuk model fungsi transfer adalah $\mathrm{b}=5, \mathrm{r}=0, \mathrm{~s}=0$ dengan deret noise ARMA ([12],1).

\section{E. Perbandingan Kedua Metode}

Setelah mendapatkan model terbaik dari metode ARIMA dan fungsi transfer untuk meramalkan volume pemakaian air maka 
perlu dikakukan pemilihan model terbaik berdasarkan kriteria out sample untuk mendapatkan hasil ramalan yang terbaik. Berikut adalah hasil perbandingan nilai RMSE metode ARIMA dan metode fungsi transfer.

Tabel 7

Perbandingan Metode

\begin{tabular}{llc}
\hline \hline \multicolumn{1}{c}{ Kategori } & \multicolumn{1}{c}{ Model } & RMSE \\
\hline Rumah Tangga & ARIMA $(1,1,[12])$ & $259.194,9769$ \\
Kelas & $\mathrm{b}=2, \mathrm{r}=0, \mathrm{~s}=0$ dan ARMA & $270.298,1453$ \\
$\begin{array}{l}\text { Menengah } \\
\text { Kebawah }\end{array}$ & $([12],[1,23])$ & \\
Rumah Tangga & ARIMA $([1,4], 1,[1,12])$ & $243.437,4785$ \\
$\begin{array}{l}\text { Kelas } \\
\text { Menengah }\end{array}$ & $\mathrm{b}=5, \mathrm{r}=0, \mathrm{~s}=0$ ARMA & $181.482,8284$ \\
$\begin{array}{l}\text { Rumah Tangga } \\
\text { Kelas }\end{array}$ & ARIMA ([1,2, $2,3,4,21], 1,[12])$ & $149.164,9779$ \\
$\begin{array}{l}\text { Menengah } \\
\text { Keatas }\end{array}$ & $\mathrm{b}=5, \mathrm{r}=0, \mathrm{~s}=0$ ARMA ([12],1) & $148.055,4276$ \\
\hline \hline
\end{tabular}

Dari Tabel 7 diatas dapat disimpulkan bahwa untuk rumah tangga kelas menengah kebawah model yang terbaik untuk meramalkan adalah ARIMA $(1,1,[12])$ karena memiliki nilai RMSE yang paling kecil, sedangkan untuk rumah tangga kelas menengah model yang terbaik adalah fungsi transfer $\mathrm{b}=5, \mathrm{r}=0$, $s=0$ dengan model deret noise ARMA $([1,4,12],[1,23])$ dan rumah tangga kelas menengah keatas model yang terbaik adalah fungsi transfer $\mathrm{b}=5, \mathrm{r}=0, \mathrm{~s}=0$ dengan model deret noise ARMA ([12],1).

Hasil peramalan volume pemakaian air (m3) berdasarkan model terbaik pada bulan November 2016 sampai Desember 2017 adalah sebagai berikut.

\begin{tabular}{cccc}
\multicolumn{4}{c}{ Tabel 8 } \\
Hasil Ramalan \\
\hline \hline Periode & KA & Kategori \\
\cline { 2 - 4 } & 4986023 & 4260486 & 3991535 \\
\hline November 2016 & 5114021 & 4159610 & 4043809 \\
Desember 2016 & 5049640 & 4240697 & 3984209 \\
Januari 2017 & 5180113 & 4173823 & 4019267 \\
Februari 2017 & 5149127 & 4188556 & 3996984 \\
Maret 2017 & 5020041 & 4163170 & 3946289 \\
April 2017 & 5026346 & 4152668 & 3937816 \\
Mei 2017 & 5292985 & 4325813 & 4097938 \\
Juni 2017 & 4911168 & 4151519 & 3884698 \\
Juli 2017 & 5336850 & 4450377 & 4130910 \\
Agustus 2017 & 5017568 & 4265926 & 3964216 \\
September 2017 & 5087755 & 4347618 & 4064453 \\
Oktober 2017 & 5051911 & 4460735 & 4053436 \\
Nopember 2017 & 5069899 & 4360334 & 4086611 \\
Desember 2017 & & & \\
\hline \hline
\end{tabular}

Tabel 8 menunjukkan hasi ramalan volume pemakaian air pada bulan Januari 2017 sampai Desember 2017. Hasil ramalan menunjukkan bahwa volume pemakaian air berfluktuasi yaitu mengalami kenaikan dan penurunan dimana pemakaian air tertinggi pada bulan Agustus 2017 sebesar $5.466 .397 \mathrm{~m}^{3}$ untuk rumah tangga kelas menengah kebawah, $4.477 .590 \mathrm{~m}^{3}$ untuk rumah tangga kelas menengah dan untuk rumah tangga kelas menengah keatas $\mathrm{p} 4.102 .573 \mathrm{~m}^{3}$.

\section{KESIMPULAN DAN SARAN}

Kesimpulan yang diperoleh pada penelitian ini adalah model Peramalan terbaik untuk kelompok pelanggan rumah tagga kelas menengah kebawah adalah ARIMA $(1,1,[12])$, sedangkan untuk kelompok pelanggan rumah tangga kelas menengah adalah fungsi transfer $b=5, r=0, s=0$ dengan deret noise ARMA $([1,4,12],[1,23])$ dan untuk rumah tangga kelas menengah keatas model yang terbaik adalah fungsi transfer $b=5, r=0, s=0$ dengan deret noise ARMA ([12],1). Volume pemakaian air rumah tangga kelas menengah kebawah bulan ini dipengaruhi oleh pemakaian air periode 1 dan 2 bulan sebelumnya. Pada rumah tangga kelas menengah, volume pemakaian air bulan ini dipengaruhi oleh volume pemakaian air rumah tangga kelas menengah pada periode 1 , 4, dan 12 bulan sebelumnya dan dipengaruhi juga oleh jumlah pelanggan pada periode 5, 6, 9 dan 17 bulan sebelumnya. Sedangkan volume pemakaian air untuk rumah tangga kelas menengah keatas bulan ini dipengaruhi oleh volume pemakaian air pada periode 12 bulan sebelumnya dan jumlah pelanggan pada periode 5 dan 17 bulan sebelumnya.

Dalam penelitian ini saran yang dapat peneliti berikan bagi Perusahaan Daerah Air Minum Kota Surabaya adalah PDAM Kota Surabaya harus mempersiapkan untuk meningkatkan kapasitas produksi air, dikarenakan volume pemakaian air yang tiap bulan terus meningkat ditambah dengan banyaknya jumlah pelanggan baru yang juga diharapkan pelanggan dapat puas terhadap pelayanan PDAM Kota Surabaya dalam hal mencukupi kebutuhan air penduduk Kota Surabaya.

\section{DAFTAR PUSTAKA}

[1] Makridakis, S., Wheelright, S.C., dan McGee, V.E. 1999. Metode dan Aplikasi Peramalan. Edisi ke-2, Jilid I. Alih Bahasa : Andriyanto, U.S., dan Basith, A. Erlangga: Jakarta.

[2] Nurina, D.L. 2013. Peramalan Volume Pemakaian Air Sektor Rumah Tangga di Kabupaten Gresik dengan Menggunakan Fungsi Transfer. Laporan Penelitian, FMIPA-ITS, Surabaya.

[3] Pradhani, F.A. 2012. Peramalan Volume Distribusi Air di PDAM Kabupaten Bojonegoro dengan Menggunakan Metode ARIMA BoxJenkins. Laporan Penelitian, FMIPA-ITS, Surabaya.

[4] Wei, W.W.S. 2006. Time Series Analysis Univariate and Multivariate Methods. United States Pearson Education, Inc. America 